\title{
Phage-displayed peptides that mimic aflatoxin B1 in serological reactivity
}

\author{
K. Thirumala-Devi ${ }^{1}$, J.S. Miller ${ }^{2}$, G. Reddy ${ }^{3}$, D.V.R. Reddy ${ }^{1}$ and M.A. Mayo ${ }^{2}$ \\ ${ }^{1}$ International Crops Research Institute for the Semi-Arid Tropics, Patancheru, Andhra Pradesh, India, ${ }^{2}$ Scottish \\ Crop Research Institute, Dundee, UK, and ${ }^{3}$ Osmania University, Hyderabad, Andhra Pradesh, India
}

513/8/00: received 18 August 2000, revised 20 October 2000 and accepted 31 October 2000

K. THIRUMALA-DEVI, J.S. MILLER, G. REDDY, D.V.R. REDDY AND M.A. MAYO. 2001.

Aims: To test phage-displayed random peptide libraries as sources of peptides that mimic the binding of aflatoxin B1 to monoclonal antibodies raised against the toxin.

Methods and Results: For two of the three MAbs tested, clones were obtained by panning, producing phage that bound specifically to MAb 13D1-1D9 (MAb 24; specific for aflatoxins B1 and G1) and MAb 6E12-1E9 (MAb 13; specific for aflatoxins B1, G1 and B2) in ELISA. The amino acid sequences of the binding peptides varied. Those binding to MAb 24 contained the sequence of '...YMD...', and those that bound to MAb 13 contained the dipeptide 'PW'.

Mimotope phage was used in a competition ELISA format for assaying aflatoxin concentrations.

Conclusions: The results show that mimotope preparations are effective substitutes for pure toxin in these ELISA procedures.

Significance and Impact of the Study: These results should contribute significantly to enhancing the safety and diminishing the costs of aflatoxin assays.

\section{INTRODUCTION}

Aflatoxins are potent carcinogenic, mutagenic, teratogenic and immuno-suppressive agents. They are produced as secondary metabolites by the fungi Aspergillus flavus and A. parasiticus (Busby and Wogan 1979) and can contaminate a variety of agricultural commodities (Butler 1974). A positive correlation has been shown between exposure to aflatoxin and the incidence of liver cancer in humans (Anon. 1962; Bosch and Peers 1991; IARC 1993). To reduce this risk, governments in many countries have set limits for permissible levels of aflatoxins in foods and feeds.

A variety of analytical methods for aflatoxin detection has been devised to ensure compliance with these standards (Chu et al. 1987). ELISA is by far the most widely used serological test for the detection of mycotoxins because of its simplicity, adaptability and sensitivity (Pestka 1988). The immunogens used to raise antibodies to aflatoxins are conjugates made to a carrier protein. This conjugation involves structural modifications to aflatoxin molecules, as well as blocking stages, either of which may lead to

Correspondence to: Dr Mike Mayo, Scottish Crop Research Institute, Invergowrie, Dundee,DD2 5DA,UK (e-mail:mmayo@scri.sari.ac.uk) substantial bridge group interference and unwanted crossreactions (Xiao et al. 1995). As the toxin antigen is essentially monovalent, assay procedures are based on competition and necessarily involve the use in the tests of pure toxin. This is hazardous and therefore, an alternative, less toxic form of aflatoxin would reduce the risks while carrying out the assays and thereby make immunoassays more widely and safely applicable.

In a search for this alternative, an attempt was made to obtain peptides that mimic aflatoxin by selection from phage-displayed random peptide libraries. Random peptide libraries displayed on phage have been shown to be powerful tools for identifying the peptide and non-peptide epitopes recognized by monoclonal antibodies (MAbs) (Smith 1991). In phage display, a peptide or a protein is fused to a coat protein of M13 or fd bacteriophage (e.g. pIII or a second recombinant copy of pVIII; Felici et al. 1991; Smith 1991), such that phage carrying the peptide also carry the encoding DNA. Determination of the recombinant $\mathrm{pVIII}$ gene sequences reveals the sequence of the binding peptide (Scott and Smith 1990). Phageborne peptides that mimic antigens in binding to antibodies are termed mimotopes (Geysen et al. 1987). There are few reports of the selection of mimotopes for antibodies 
to non-proteinaceous chemicals, other than biotin (Weber et al. 1992) and carbohydrates (Hoess et al. 1993). Recently, Yuan et al. (1999) showed that it was possible to obtain mimotopes to MAbs raised against the mycotoxin deoxynivelenol. The mimotopes obtained were essentially of a single amino acid sequence.

Aflatoxins differ slightly in their chemical formulae; $\mathrm{B} 1$ is the principal hazard from fungal contamination of peanuts. MAbs raised to an aflatoxin Bl-bovine serum albumin conjugate (Thirumala Devi et al. 1999) cross-reacted with the other main aflatoxin types (B2, G1 and G2) to different extents. In this paper, the selection of mimotopes for aflatoxins, using two of these MAbs that differed in specificity, and the application of these mimotopes in ELISA for quantitative estimation of aflatoxins, is reported for the first time.

\section{MATERIALS AND METHODS}

\section{Reagents}

Aflatoxin B1 (AFB1), goat anti-rabbit IgG-alkaline phosphatase (ALP) conjugate, goat anti-mouse IgG-ALP conjugate, $p$-nitrophenyl phosphate, bovine serum albumin (BSA), aflatoxin B1-BSA conjugate, tetracycline and polyethylene glycol (PEG), were all purchased from the Sigma Chemical Co. Microtitre plates (Maxi-sorp F96) and immuno-tubes (Maxi-sorp) were obtained from Nalge Nunc International, Denmark. Peptone, yeast extract and agar were obtained from life technologies Gibco BRL. All other chemicals were reagent grade or chemically pure.

\section{Monoclonal antibodies for aflatoxin B1}

Anti-aflatoxin B1 monoclonal antibodies were those described by Thirumala Devi et al. (1999). MAb 13D1-1D9 (here coded MAb 24) cross-reacted with aflatoxin G1, but not B2, 6E.12-1E5 (here named MAb 13) cross-reacted with aflatoxins $B 2, G 1$ and G2, and MAb 10D5-1A11 did not cross-react appreciably with any of the other aflatoxins (Thirumala Devi et al. 1999). Immunoglobulins were concentrated from tissue culture supernatant or ascitic fluid by ammonium sulphate precipitation (Harlow and Lane 1988).

\section{Peptide libraries}

The random phage displayed peptide libraries, Cys-4 and Cys-6, used in this study were provided by G. Smith (University of Missouri, Columbia, USA). Each library consists of fd phage carrying a second copy of gene VIII that has at its N-terminus a randomized sequence in which cysteine codons are four or six codons apart. The cysteines are designed to constrain by cross-linking the conformations that the peptides may adopt (Ziegler et al. 1998).

\section{Affinity selection of phage by panning}

Panning was as described by Ziegler et al. (1998), using immuno-tubes coated with MAbs at $10 \mu \mathrm{g} \mathrm{ml} \mathrm{m}^{-1}$. After blocking, phage were bound and eluted, and then used to infect Escherichia coli TG-1 cells. After amplification, phage were subjected to two further rounds of panning to enrich the population with binding phage.

\section{Immunological assay for affinity-purified phage}

Following the third round of panning, single tetracyclineresistant colonies were transferred to $5 \mathrm{ml} \mathrm{LB-TET}$ and grown at $37^{\circ} \mathrm{C}$ for $18 \mathrm{~h}$. Cells were removed by centrifugation at $17000 \mathrm{~g}$ for $5 \mathrm{~min}$, and the culture media were tested by ELISA using microtitre plates. At each step, the plates were incubated for $1 \mathrm{~h}$ at $37^{\circ} \mathrm{C}$. Initially, plates were coated with IgG at $10 \mu \mathrm{g} \mathrm{m}{ }^{-1}$ in $0.2 \mathrm{~mol} \mathrm{l}^{-1}$ sodium carbonate, $\mathrm{pH} 9 \cdot 6$. In the second step, plates were blocked with $200 \mu \mathrm{l}$ well $^{-1}$ of $3 \%$ MPBS. Phage particles in $80 \mu \mathrm{l}$ were mixed with $20 \mu \mathrm{l}$ of MPBS. A mixture of rabbit antiM13 antibody (1 : 500) and anti-rabbit IgG conjugated to alkaline phosphatase (1:100 000 dilution) was used to detect the phage. Substrate ( $p$-nitrophenyl phosphate at $1 \mathrm{mg} \mathrm{ml}^{-1}$ ) was added and absorbance at $405 \mathrm{~nm}$ was read in an ELISA plate reader ('Titertek) after $1 \mathrm{~h}$ at room temperature. Selected individual clones were characterized by DNA sequencing and ELISA.

\section{Indirect competitive ELISA with phage-displayed peptides}

To determine the optimum number of phage to use in ELISA, different dilutions of phage particles in carbonate coating buffer were added to the ELISA plate and incubated overnight at $4^{\circ} \mathrm{C}$. After blocking, a mixture of $\mathrm{MAb}$ and goat anti-mouse-alkaline phosphatase conjugate was added and the ELISA was completed as described. An indirect ELISA procedure similar to that reported for aflatoxins (Thirumala Devi et al. 1999) was used. Microtitre plate wells were coated with $150 \mu \mathrm{l}$ of phage at $10^{11} \mathrm{ml}^{-1}$ that carried peptides in $0.2 \mathrm{~mol} \mathrm{l}^{-1}$ sodium carbonate, $\mathrm{pH} \mathrm{9.6}$, and incubated overnight at $4^{\circ} \mathrm{C}$. The plates were washed and blocked as above for panning elution selection. MAbs in 50 $\mu \mathrm{l}$ were added to various concentrations of AFB1 $(0-10 \mu \mathrm{g}$ $\mathrm{ml}^{-1}$ in PBS). The mixtures were added to the phage-coated microtitre plate wells $\left(150 \mu \mathrm{l} \mathrm{well}^{-1}\right)$ and the preparations were incubated at $37^{\circ} \mathrm{C}$ for $1 \mathrm{~h}$. After washing four times with PBS-T, the plates were incubated with goat anti- 
mouse-ALP conjugate at $37^{\circ} \mathrm{C}$ for $1 \mathrm{~h}$. The amounts of bound enzyme were determined as described above. The results of inhibition tests were analysed using Genstat 5 and logistic curves were fitted to the data (Genstat 5 Committee 1987).

\section{Nucleotide sequencing}

Phage particles were recovered by PEG-precipitation and single-stranded DNA was extracted from them by phenolchloroform treatment (Sambrook et al. 1989). Sequencing was done using an ABI PRISM dye primer cycle sequencing ready reaction kit (Perkin Elemer Applied Biosystems, Warrington, UK). The primer was complementary to DNA encoding the recombinant pVIII gene, downstream of the peptide insert. Sequences were analysed using the Genetics Computer Package (Devereux et al. 1984).

\section{Ultraviolet irradiation of phage particles}

Phage particles were u.v.-irradiated at $254 \mathrm{~nm}$, with doses of

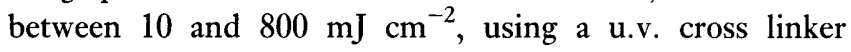
(Stratalinker UV crosslinker; Stratagene Ltd, Cambridge, UK). The treated phage particles were then used to infect log-phase TG-1 cells, or assayed by ELISA.

\section{Sample preparation}

Groundnut samples were obtained in $200 \mathrm{~g}$ quantities. After a thorough mixing, three $15 \mathrm{~g}$ sub-samples were drawn from each $200 \mathrm{~g}$ sample. Each sub-sample was finely ground and then extracted in $75 \mathrm{ml} \mathrm{30 \%} \mathrm{methanol,} \mathrm{containing} 0.5 \%$ $\mathrm{KCl}$, by blending in a Waring blender followed by shaking for $30 \mathrm{~min}$. The extract was filtered through Whatman no. 41 filter paper and diluted to $1: 10$ with PBS-T/BSA for processing by ELISA.

\section{Indirect competitive ELISA procedure for processing groundnut samples}

The protocol was similar to that for indirect competitive ELISA for phage-displayed peptides (as described above), with the exception that aflatoxin standards in $100 \mu \mathrm{l}$ volumes, ranging from $100 \mathrm{ng} \mathrm{ml}^{-1}$ to $100 \mathrm{pg} \mathrm{ml}^{-1}$, were prepared in a diluted extract from groundnuts. Groundnut samples that did not contain aflatoxins were extracted in methanol as described above, filtered, and used at a $1: 10$ dilution prepared in PBS-T/BSA. Test samples were also diluted to 1 : 10 in PBS-T/BSA. A $100 \mu \mathrm{l}$ aliquot of each sample was added to wells containing $50 \mu \mathrm{l}$ of antiserum. The wells were washed four times with PBS-T and incubated with goat anti-mouse ALP-conjugate at $37^{\circ} \mathrm{C}$ for $1 \mathrm{~h}$. The amounts of enzyme bound were determined as described above. Standard curves were obtained by plotting $\log _{10}$ values of aflatoxin $B 1$ standards against optical density (O.D.) at $\mathrm{A}_{405}$.

\section{RESULTS}

\section{Screening of random peptide phage libraries for the selection of specific phages by panning}

Tubes were coated with MAb 24 or MAb 13 and used for selection using either Cys-4 or Cys-6 libraries. Irrespective of the library used, the proportion of phage that bound (input titre/output titre) increased after each round. After the third round, input and output titres were about $10^{13}$ $\mathrm{ml}^{-1}$. All 20 of 20 clones from the Cys-4 library, and four of 20 from the Cys-6 library, yielded phage that bound to MAb 24 ( $\mathrm{A}_{405}$ of $>0.5$ to 2 in $1 \mathrm{~h}$ using DAS ELISA). From the 21 clones obtained using MAb 13, 11 from the Cys-4 library and 12 from the Cys-6 library gave positive results in ELISA tests. No clones were obtained from either library yielding phage that bound to MAb 10D5-1A11.

\section{Optimum number of phage particles for coating the ELISA plate}

ELISA plates were coated with different amounts of phage particles to establish the number of particles that were needed to give a useful response in phage ELISA. Figure 1 shows the results of ELISA of four mimotope clones, at different concentrations, assayed using either MAb 24 (clones 24-4 and 24-6) or MAb 13 (clones 13-4 and 13-6). The best results were obtained with phage concentrations of $10^{11} \mathrm{ml}^{-1}$. In parallel tests, plates coated with an unrelated Cys-4 phage clone at $10^{11} \mathrm{ml}^{-1}$ gave an $\mathrm{A}_{405}$ of $<0 \cdot 1$.

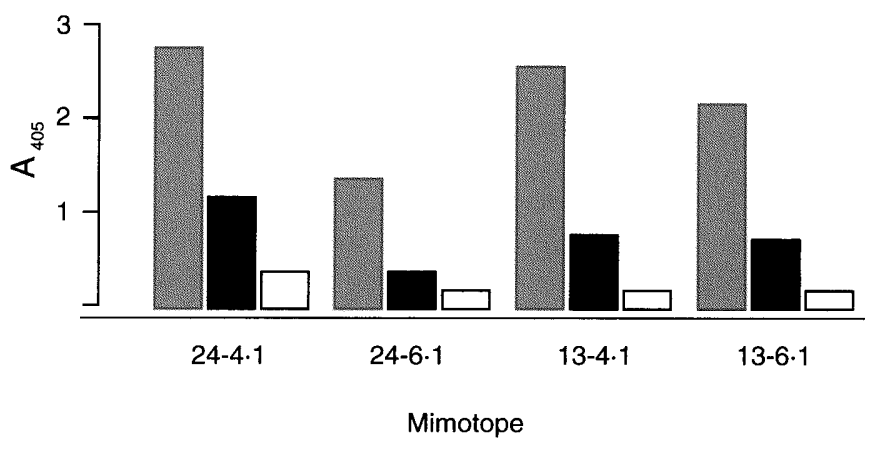

Fig. 1 Results of indirect ELISA with four phage mimotopes (24-4·1, $24-6 \cdot 1,13-4 \cdot 1,13-6 \cdot 1)$ at concentrations of (期) $10^{11},(\square) 10^{10}$ or ( $\square$ ) $10^{9} \mathrm{ml}^{-1}$ 


\section{Specificity tests}

The mimotopes $24-4 \cdot 1,24-6 \cdot 1,13-4 \cdot 1$ and $13-6 \cdot 1$ were tested in phage ELISA at $10^{11} \mathrm{ml}^{-1}$ using dilutions of polyclonal antibody raised against an aflatoxin B1-BSA conjugate. The results for different mimotopes were indistinguishable. For example, a fourfold decrease in antibody concentration decreased the ELISA readings obtained in $1 \mathrm{~h}$ from $1.04,1.07,1.05$ or 1.08 to $0.43,0.47$, 0.45 or 0.43 for each mimotope, respectively. In ELISA tests, mimotopes obtained using MAb 24 did not bind to $\mathrm{MAb} 13$, and neither did MAb 13 mimotopes bind to MAb 24.

To test the specificity of the mimotopes, indirect competitive ELISA was done with mimotopes 24-4·1 and 13-4.1 using the corresponding MAbs. Figure 2 shows the results. For both mimotopes, the homologous toxin was the most competitive; other toxins were less competitive in the order G2<B2<G1. With 24-4.1 (Fig. 2a), B2, and especially G2, were much less competitive whereas with $13-4 \cdot 1$, the differences between toxins were less marked. The median doses (the toxin concentrations that resulted in an estimated $50 \%$ inhibition of binding) and the slopes of the curves at the median were calculated from the curves fitted to the data using the formula:

$\mathrm{A}_{405}=\mathrm{A}+\mathrm{C} /(1+\exp (-\mathrm{B} *(\mathrm{X}-\mathrm{M})))$

where $\mathrm{A}$ and $\mathrm{C}$ are the asymptotes, $\mathrm{M}$ is the median dose and $\mathrm{B}$ is the slope at the median dose.

Table 1 shows the results. These confirm the impressions from Fig. 2 that the strongest competition, as judged by the slopes of the lines, was with Bl, the 'homologous' antigen, and the weakest competition was with G2.

\section{Effect of dithiothreitol}

The peptide sequences displayed by phage from the Cys- 4 and Cys-6 libraries contain cysteine residues that are intended to cross-link, so as to create a loop structure of either four or six amino acids. Mimotope phage were treated with dithiothreitol, prior to being used to coat ELISA plates, in order to prevent the formation of this cross-link. With all clones tested $(24-4 \cdot 1,24-4 \cdot 2,24-6 \cdot 1,13-4 \cdot 1,13-4 \cdot 2,13-6 \cdot 1)$, the effects of dithiothreitol treatment were to increase the binding of the corresponding MAbs by between twofold and fivefold.

\section{Effect of U.v. irradiation on phage infectivity}

The infectivity of a dilute sample of mimotope $24-4 \cdot 1$ was decreased from about 4500 colonies $\mathrm{ml}^{-1}$ to about 60
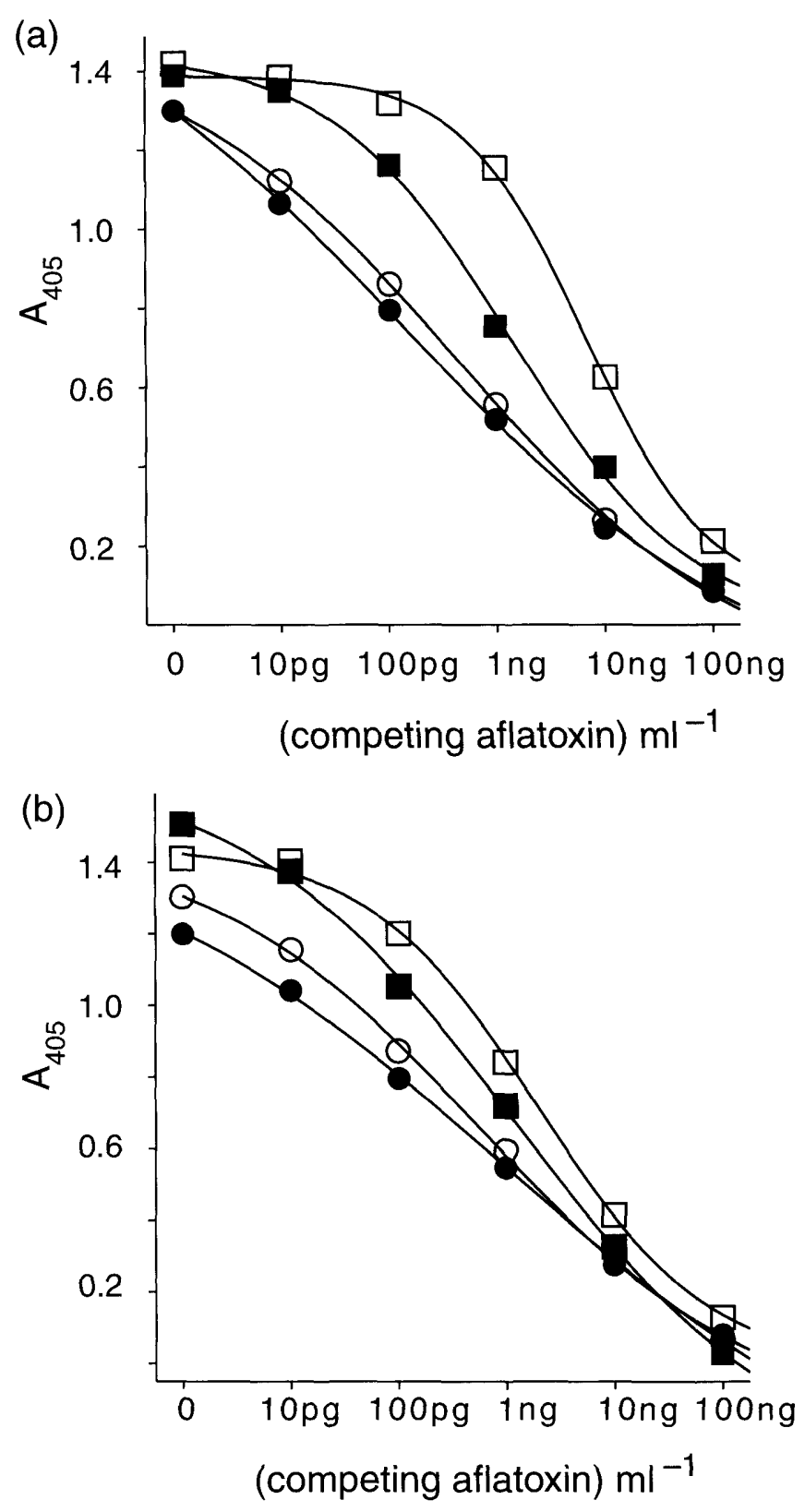

Fig. 2 Competition between pure aflatoxins $(\bullet) \mathrm{B} 1,(\bigcirc) \mathrm{B} 2,(\mathbf{\square}) \mathrm{G1}$ and $(\square)$ G2, in the solution and phage mimotopes (24-4.1 and 13-4.1) coated on ELISA plate surface for binding to MAbs, in indirect competitive ELISA. (a) Mimotope 24-4.1 binding to MAb 24. (b) Mimotope $13-4 \cdot 1$ binding to MAb 13

colonies $\mathrm{ml}^{-1}$ by irradiation at $20 \mathrm{~mJ} \mathrm{~cm}^{-2}$, and was abolished by larger doses. At these doses, there was little effect on MAb binding as assessed by phage ELISA. Phage irradiated at $50 \mathrm{~mJ} \mathrm{~cm}^{-2}$ bound about $90 \%$ of the amount of $\mathrm{MAb}$ bound by untreated samples. Binding decreased to 
Table 1 Parameters of the inhibition dose curves shown in Fig. 2

\begin{tabular}{llllll}
\hline & \multicolumn{2}{l}{ Mimotope 24-4.1 } & & \multicolumn{2}{l}{ Mimotope 13-4.1 } \\
\cline { 2 - 3 } Inhibitor & Median dose* & Slope & & Median dose & Slope \\
\hline B1 & 1.38 & -0.6044 & & 1.04 & -0.53 \\
B2 & 1.39 & -1.2032 & & 1.22 & -0.80 \\
G1 & 0.45 & -0.7495 & & 0.58 & -0.79 \\
G2 & 6.77 & -1.7623 & & 1.98 & -1.27 \\
\hline
\end{tabular}

${ }^{*} \mathrm{ng} \mathrm{ml^{-1 }}$.

$70 \%$ following irradiation with $100 \mathrm{~mJ} \mathrm{~cm}^{-2}$, and further after higher doses.

\section{Recovery of aflatoxin B1 from groundnut samples}

In order to test the effectiveness of the phage ELISA, 10 $200 \mu \mathrm{g} \mathrm{kg}^{-1}$ of aflatoxin $\mathrm{B} 1$ were added to finely ground $10 \mathrm{~g}$ samples, which were then extracted and assayed. Table 2 lists the results from each of two ELISA plates. The recoveries were between 92 and $110 \%$; the average recoveries on each plate were $101.3 \%$ and $98.9 \%$.

To assess the assay method in practice, samples were taken from farmers' fields that were presumed to be at high risk of aflatoxin contamination because of drought. These were extracted and assayed by using competition ELISA. The results (Table 3) show that five samples were contaminated to various extents. Results for duplicate samples and duplicate plates were within $10 \%$. The permissible level in India for aflatoxin B1 contamination is currently $30 \mu \mathrm{g} \mathrm{kg}^{-1}$.

\section{Mimotope sequences}

For mimotope phage from either library, the nucleotide sequences were determined for the section of recombinant

Table 2 Efficiencies of extraction

\begin{tabular}{lcc}
\hline \multirow{2}{*}{$\begin{array}{l}\text { Concentration in sample } \\
\left(\mu \mathrm{g} \mathrm{kg}^{-1}\right)\end{array}$} & Recovery* \\
\cline { 2 - 3 } & Plate 1 & Plate 2 \\
\hline 10 & $98 \%$ & $102 \%$ \\
20 & $102 \cdot 5 \%$ & $110 \cdot 4 \%$ \\
40 & $105 \%$ & $96 \%$ \\
80 & $99 \cdot 9 \%$ & $94 \cdot 1 \%$ \\
100 & $100 \cdot 7 \%$ & $99 \cdot 6 \%$ \\
150 & $101 \cdot 1 \%$ & $91.9 \%$ \\
200 & $102 \cdot 2 \%$ & $98 \cdot 5 \%$ \\
Mean & $101 \cdot 3 \%$ & $98 \cdot 9 \%$ \\
\hline
\end{tabular}

*Measured concentration/known concentration $\times 100$.
Table 3 Assays of groundnut samples for aflatoxin B1

\begin{tabular}{|c|c|c|c|c|c|}
\hline \multirow[b]{3}{*}{ Sample } & \multicolumn{4}{|c|}{ [aflatoxin $\mathrm{B} 1$ ] $\left(\mu \mathrm{g} \mathrm{kg}^{-1}\right)$} & \multirow[b]{3}{*}{ Result } \\
\hline & \multicolumn{2}{|l|}{ Plate 1} & \multicolumn{2}{|l|}{ Plate 2} & \\
\hline & Test 1 & Test 2 & Test 1 & Test 2 & \\
\hline 1 & $15 \cdot 2$ & $14 \cdot 0$ & $19 \cdot 8$ & $21 \cdot 6$ & + \\
\hline 2 & $<10$ & $<10$ & $<10$ & $<10$ & - \\
\hline 3 & 101 & $89 \cdot 3$ & 101 & 113 & + \\
\hline 4 & $55 \cdot 1$ & $49 \cdot 0$ & $46 \cdot 8$ & $45 \cdot 1$ & + \\
\hline 5 & 302 & 276 & 295 & 286 & + \\
\hline 6 & $<10$ & $<10$ & $<10$ & $<10$ & - \\
\hline 7 & $<10$ & $<10$ & $<10$ & $<10$ & - \\
\hline 8 & 329 & 314 & 331 & 331 & + \\
\hline 9 & $<10$ & $<10$ & $<10$ & $<10$ & - \\
\hline 10 & $<10$ & $<10$ & $<10$ & $<10$ & - \\
\hline
\end{tabular}

pVIII gene that encoded the randomized peptide sequence. These are shown in Fig. 3. Each sample was sequenced twice. All sequences were confirmed except where shown in Fig. 3. The altered sequences presumably arose during phage propagation between the two sequencing experiments, either from the appearance of point mutations, or from the sample being a mixture of phages that changed in preponderance.

The sequences of mimotopes to MAb 24 suggested a consensus sequence of '...CYMD-C...'. Those for mimotopes to MAb 13 did not suggest a clear consensus, although the dipeptide ' $\mathrm{PW}$ ' was present in most, and all were particularly rich in proline residues.

\section{DISCUSSION}

The results show that by panning phage-displayed peptide libraries, it is possible to obtain peptides that mimic the binding of aflatoxin B1 to antibodies raised against it. However, with one of the three MAbs tried, no mimotopes were obtained from either library. This MAb does not crossreact with other aflatoxins (Thirumala Devi et al. 1999) and it is possible that the epitope involved in this highly specific binding cannot be mimicked by peptides. However, mimotopes were obtained to the other two MAbs and these had similar properties to the toxin in ELISA tests. All mimotopes reacted equally well with polyclonal antibodies. In a competitive ELISA, aflatoxin B1 could compete with the selected peptides for binding to $\mathrm{MAb}$, while the synthetic peptide also competed with aflatoxin for binding to the same antibody. This strongly suggests that these clones bind to the same antigen-binding site of the MAb. However, in competition ELISA with aflatoxins B2, G1 and G2, the mimotope from the set binding to MAb 24 was differently affected by competition from the one binding to MAb 13 
Fig. 3 Amino acid sequences of mimotope peptides. Nucleotide sequences were determined for the part of the recombinant gene VIII that encodes amino acids randomized in the libraries Cys-4 and Cys-6. Where two amino acids are shown, a second sequencing experiment yielded different sequences. The contiguous sequence is that obtained first; differences are shown below the altered amino acid

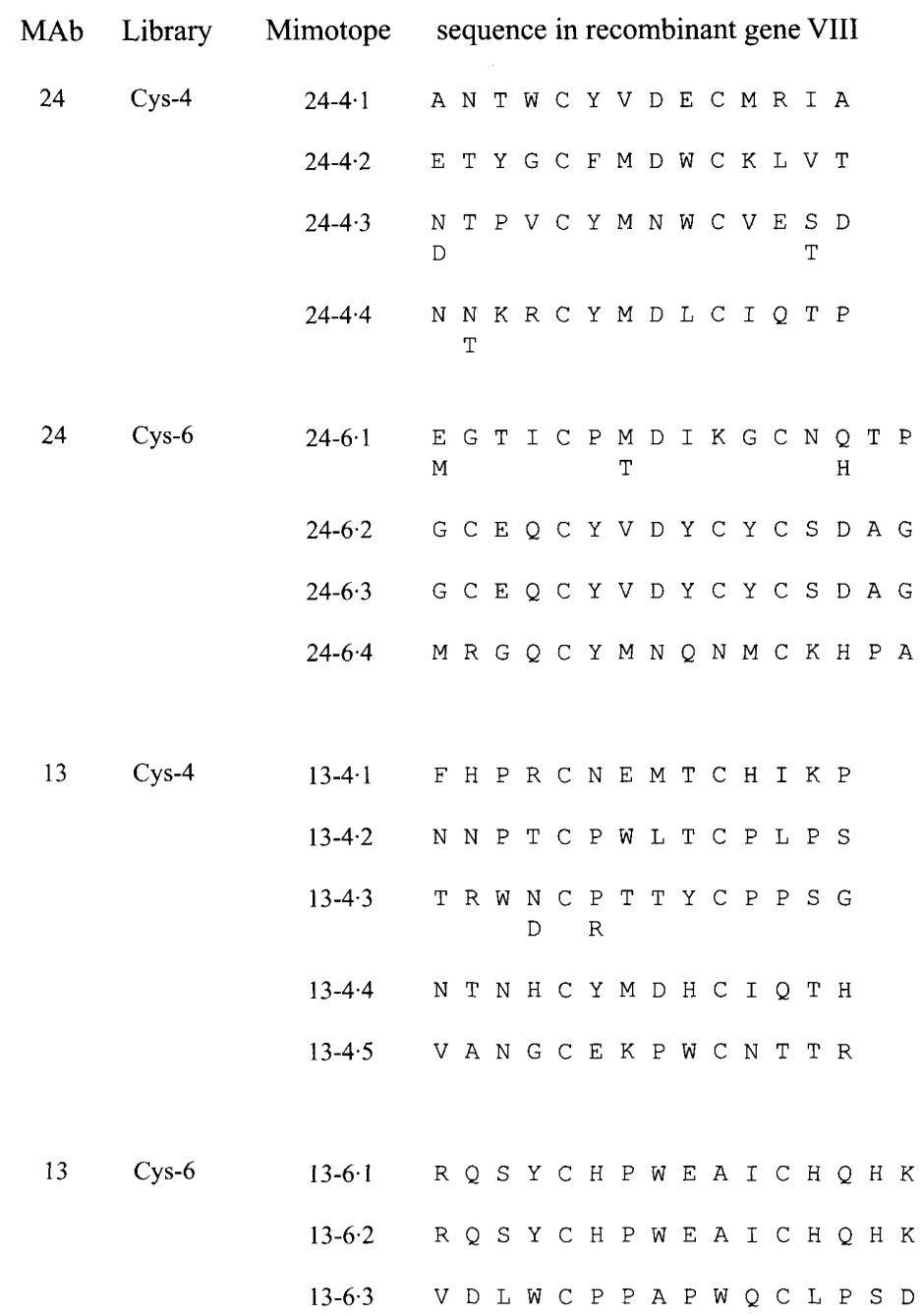

(Fig. 2). The differences among the slopes (Table 1) reflected the different extents of cross-reactivity each MAb had with heterologous aflatoxins (Thirumala Devi et al. 1999). These were, $\mathrm{B} 1=\mathrm{G} 1 \gg \mathrm{B} 2$ and $\mathrm{G} 2$ for MAb 24, and $\mathrm{B} 1>\mathrm{G} 1=\mathrm{B} 2 \gg \mathrm{G} 2$ for MAb 13. Thus, in these tests, $\mathrm{Gl}$ was the most similar aflatoxin to $\mathrm{B} 1$. This suggests that the change from a five-membered ring to a sixmembered ring containing an extra oxygen atom, which distinguishes $B$ aflatoxins from $G$ aflatoxins, alters the accuracy of the mimicry by the peptides less than does the change from a double bond to a single bond, in a different ring, which distinguishes aflatoxins $\mathrm{B} 1$ and $\mathrm{G} 1$ from $\mathrm{B} 2$ and G2.

The amino acid sequences of the mimotope peptides differed among the clones isolated, although some residues, especially aromatic amino acids, were abundant. MAb 24 mimotopes contained one or more tyrosine residues and MAb 13 mimotopes contained tryptophan residues. This may reflect a degree of molecular mimicry by the ring structures in the aromatic amino acids for the ring structures in the aflatoxin molecules. In sequence, the MAb 24 mimotope peptides were unrelated to those for MAb 13 . Presumably, the binding pockets in the two MAbs differ appreciably despite the simplicity of the common immunogen to which they were raised.

By its nature, the phage display method tends preferentially to isolate strongly binding phage. The present results show that aflatoxin MAbs select several approximately equally strongly binding peptides. This contrasts with the results obtained by Yuan et al. (1999) with mimotopes isolated from an unconstrained library for MAbs specific to the toxin deoxynivalenol. Possibly, the mimotope these authors obtained is a much stronger binder than any others present in the library used for the panning.

Aflatoxins are important human and animal toxins, and so care must be taken to avoid direct contact during analysis. 
The possibility of replacing toxins in diagnostic procedures with presumably non-toxic peptides should therefore result in enhanced laboratory and environmental safety. This advantage could be even more marked when diagnostic test kits are used in 'the field' by relatively unskilled operators unused to laboratory discipline.

Although many mimotope peptides for protein antigens have been isolated from phage-displayed peptide libraries (e.g. Scott et al. 1992; Hoess et al. 1993), this is only the second report of mimotopes for a non-proteinaceous, low molecular weight mycotoxin, and the first report of aflatoxin mimotopes. Sixteen somewhat related mimotope peptides have been identified that mimic the binding of aflatoxin to specific antibodies, and the potential for using these peptides in aflatoxin immunoassays has been demonstrated. This use of peptide libraries as sources of reagents in immunoassays could well be applicable in ELISA tests for other mycotoxins.

\section{ACKNOWLEDGEMENTS}

This document is an output from a project (R7083) funded by the UK Department for International Development (DFID) for the benefit of developing countries. The views expressed are not necessarily those of DFID. The authors are grateful to Dr Angelika Zeigler and Michele Liney for helpful discussions during this work, and to Jim McNicol, BioSS, for statistical guidance. MAM acknowledges financial support from the Scottish Executive Rural Affairs Department. KT-D and DVRR are supported by ICRISAT.

\section{REFERENCES}

Anon. (1962) Progress in cancer research: Potent liver toxin and carcinogen produced in groundnuts as a result of infection with the fungus Aspergillus flavus. British Medical Journal 2(5298), 172-174.

Bosch, F.X. and Peers, F. (1991) Aflatoxins: data on human carcinogenic risk. In relevance to human cancer of $\mathrm{N}$-Nitroso compounds. In Tobacco and Mycotoxins ed. O'Neill, J.K., Chen, J. and Barstch, H. pp. 48-53. Lyon, France: International Agency for Research on Cancer.

Busby, W.F. Jr and Wogan, G.N. (1979) Food-borne mycotoxins and alimentary mycotoxicoses. In Food-Borne Infections and Intoxications 2nd edn, ed. Riemann, H. and Bryan, F.L. pp. 519-610. New York: Academic Press.

Butler, W.H. (1974) Aflatoxins. In Mycotoxins ed. Purchase, I.F.H. pp. 1-28. New York: Elsevier Scientific Publishing Co.

Chu, F.S., Fan, T.S.L., Zhang, G.-S., Xu, Y.-C., Faust, S. and McMohan, P.L. (1987) Improved enzyme-linked immunosorbant assay for aflatoxin $\mathrm{B} 1$ in agricultural commodities. Fournal of the Association of Official Analytical Chemists 70, 854-857.
Devereux, J., Haeberli, P. and Smithies, O. (1984) A comprehensive set of nucleotide sequence analysis program for the VAX. Nucleic Acids Research 12, 387-395.

Felici, F., Castagnoli, L., Musacchio, A., Jappelli, R. and Cesareni, G. (1991) Selection of antibody ligands from a large library of oligopeptides expressed on a multivalent exposition vector. Fournal of Molecular Biology 222, 301-310.

Genstat 5 Committee (1987) Genstat 5 Reference Manual. Oxford: Clarendon Press.

Geysen, H.M., Rodda, S.J., Mason, T.J., Tribbick, G. and Schoofs, P.G. (1987) Strategies for epitope analysis using peptide synthesis. fournal of Immunological Methods 102, 259-274.

Harlow, E. and Lane, D. (1988) eds. Antibodies: a Laboratory Manual. New York: Cold Spring Harbor Laboratory.

Hoess, R., Brinkmann, U., Handel, T. and Pastan, I. (1993) Identification of a peptide, which binds to the carbohydrate-specific monoclonal antibody B3. Gene 128, 43-49.

IARC (1993) IARC Monographs on the Evaluation of Carcinogenic Risks to Humans. V.56. Some Naturally Occurring Substances: Food Items and Constituents, Heterocyclic Aromatic Amines and Mycotoxins. Lyon, France.

Pestka, J.J. (1988) Enhanced surveillance of food borne mycotoxins by immunochemical assay. Fournal of the Association of Official Analytical Chemists 71, 1075-1081.

Sambrook, J., Fritsch, E.F. and Maniatis, T. (1989) Molecular Cloning: A Laboratory Manual. Cold Spring Harbor, NY: Cold Spring Harbor Laboratory Press.

Scott, J.K., Loganathan, D., Eusley, R.B., Gong, X. and Goldstein, I.J. (1992) A family of concanavalin A-binding peptides from a hexapeptide epitope library. Proceedings of the National Academy of Sciences USA 89, 5398-5402.

Scott, J.K. and Smith, G.P. (1990) Searching for peptide ligands with an epitope library. Science 249, 386-390.

Smith, G.P. (1991) Surface presentation of protein epitopes using bacteriophage expression systems. Current Opinions in Biotechnology 2, 668-673.

Thirumala Devi, K., Mayo, M.A. et al. (1999) Production and characterization of monoclonal antibodies for aflatoxin B1. Letters in Applied Microbiology 29, 284-288.

Weber, P.C., Pantoliao, M.W. and Thompson, L.D. (1992) Crystal structure and ligand-binding studies of a screened peptide complexed with streptavidin. Biochemistry 31, 9350-9354.

Xiao, H., Clarke, J.R., Marquardt, R.R. and Froblich, A.A. (1995) Improved methods for conjugating selected mycotoxins to carrier proteins and dextran for immunoassays. Journal of Agricultural Food Chemistry 43, 2092-2097.

Yuan, Q., Pestka, J.J., Hespenheide, B.M., Kuhn, K.A., Linz, J.E. and Hart, L.P. (1999) Identification of mimotope peptides which bind to the mycotoxins deoxynivalenol-specific monoclonal antibody. Applied and Environmental Microbiology 65, 3279-3286.

Ziegler, A., Mayo, M.A. and Torrance, L. (1998) Synthetic antigen from a peptide library can be an effective positive control in immunoassays for the detection and identification of two geminiviruses. Phytopathology 88, 1302-1305. 